\title{
STUDI LITERASI INFORMASI PADA PEGAWAI NEGERI SIPIL (PNS) TENAGA PENDIDIK
}

\author{
Haryati \\ Peneliti Madya pada Balai Pengkajian dan Pengembangan Komunikasi dan Informatika Bandung \\ Jl. Pajajaran No. 88 Bandung - 40173 \\ (Makalah diterima tanggal 24 Oktober 2011 - Revisi tanggal 7 November 2011)
}

\begin{abstract}
Abstrak
Penelitian "Studi literasi informasi (information literacy) PNS Tenaga Pendidik", secara umum bertujuan untuk melakukan pemetaan tingkat literasi informasi (information literacy) tenaga pendidik di lingkungan PNS di Provinsi Jambi, Bengkulu, Kepulauan Bangka-Belitung dan DKI Jakarta. Populasi, yakni para tenaga pendidik (guru) PNS di Provinsi Jambi, Kepulauan Bangka Belitung, Bengkulu, dan DKI Jakarta. Penentuan sampel penelitian menggunakan teknik sampel proporsional berstrata (Stratified Proportional Simple Random Sampling), jumlah sampel penelitian ditetapkan quota sejumlah 400. Hasil penelitian memperlihatkan, tingkat literasi informasi (information literacy) tenaga pendidik di lingkungan PNS di Provinsi Jambi sudah baik namun masih perlu mendapat perhatian pada kemampuan yang menyangkut publishing literacy, di Provinsi Babel dan Provinsi DKI Jakarta sudah baik, sedangkan di Provinsi Bengkulu masih kurang terutama pada kemampuan publishing literacy, resource literacy, dan critical literacy.
\end{abstract}

Kata Kunci: literasi informasi, tenaga pendidik

\begin{abstract}
Research "The study of information literacy (information literacy) Educators Public Servants $(P N S) "$, generally aimed at mapping the level of information literacy (information literacy) educators in public servants in the province of Jambi, Bengkulu, Bangka-Belitung and Jakarta. Population are educators (teachers) public servants in the province of Jambi, Kepulauan Bangka-Belitung, Bengkulu, and Jakarta. Determination the research sample using proportional stratified sampling technique (Simple Proportional Stratified Random Sampling), the number of samples is determined research quota number 400. The results showed, the level of information literacy (information literacy) educators in public servants in the province of Jambi is good but still requires attention to the literacy skills associated with the issuance, in the province of Bangka-Belitung, and Jakarta has been good, while in the province of Bengkulu still lacking, especially on the ability of publishing literacy, literacy resources, and critical literacy.
\end{abstract}

Keyword: information literacy, educators

\section{PENDAHULUAN}

VISI Masyarakat Informasi Indonesia 2015 (MII 2015) - sesuai dengan agenda World Summit on the Information Society (WSIS), di Jenewa pada tahun 2003 dan di Tunisia tahun 2005, yaitu dibangunnya masyarakat informasi pada tataran global, dengan sasaran terwujudnya masyarakat global, yaitu :

"Di masyarakat informasi yang inklusif, berpusat pada manusia dan berorientasi secara khusus pada pembangunan, di mana setiap orang dapat mencipta, mengakses, menggunakan, dan berbagi informasi serta pengetahuan, sehingga 


memungkinkan $\begin{gathered}\text { setiap } \\ \text { individu, } \\ \text { komunitas } \\ \text { menggunakanat }\end{gathered}$
mereka untuk mendorong pembangunan
kemampuan
berkelanjutan dan meningkatkan mutu
hidup mereka, berdasar tujuan dan
prinsip Piagam Perserikatan Bangsa
Bangsa dan menaati sepenuhnya
Deklarasi Universal Hak Asasi
Manusia".

Konsekuensi atas kesepakatan WSIS menjadikan informasi bersifat borderless, dapat mengalir kemana saja tanpa batas negara. Perkembangan teknologi dan informasi yang pesat, memungkinkan siapa pun, setiap orang dapat mengakses, menggunakan, dan berbagi informasi serta pengetahuan. Seiring dengan ledakan informasi dan penerapan TIK tersebut, masyarakat akan berkembang memasuki peradaban masyarakat informasi (information society), yaitu peradaban di mana informasi sudah menjadi komoditas utama, dan interaksi antar manusia sudah berbasis teknologi informasi dan komunikasi (TIK).

Perkembangan teknologi informasi secara tidak langsung mempunyai peran strategis dalam mengembangkan masyarakat informasi. Karena itu guna menuju transformasi masyarakat menuju masyarakat informasi, tidak saja membutuhkan infrastruktur yang handal, dan regulasi (peraturan) yang mendukung, tetapi juga sumber daya manusia (SDM) atau brainware dengan tingkat literasi media yang memadai dan kemampuan mengeksplorasi konten (literasi informasi).

Di negara maju sudah lama berkembang suatu konsep tentang literasi informasi. Pengertian dari literasi informasi adalah: "Information literacy is knowing when and why you need information, where to find it, and how to evaluate, use and communicate it in an ethical manner." (http://www.cilip.org.uk)

Kebutuhan akan literasi informasi mendorong orang untuk mengembangkan teknologi informasi. Tuntutan penguasaan dan penggunaan TIK baik bagi individu maupun organisasi/perusahanan dewasa ini semakin nyata dikarenakan beberapa hal sebagai berikut: "Ketatnya persaingan di pasar global sehingga kecepatan memperoleh informasi sangat menentukan dalam mengatur strategi bersaing; Perubahan pasar yang demikian cepat menuntut penguasaan TIK untuk mencermati dan mengantisipasinya; Perkembangan IPTEK mutakhir menuntut penggunaan dan pemanfaatan TIK yang semakin optimal; Tuntutan kemudahan akses untuk membangun relationship dalam pengembangan diri maupun organisasi; dan TIK telah menjadi trend kehidupan di era global" (Noor Fitrihana: 2008).

Perkembangan Teknologi Informasi dan Komunikasi yang demikian pesat telah mendorong peran strategis informasi sebagai suatu modal dasar pembangunan. Dari uraian di atas sangat nyata urgensi kemampuan literasi informasi bagi seseorang agar mampu bersaing di era global. Berdasarkan pemikiran tersebut, diperlukan studi untuk melakukan penelitian bagaimana tingkat literasi informasi (information literacy) pada aparat pemerintah/PNS Tenaga Pendidik?

Berdasarkan latar belakang penelitian di atas, maka permasalahan pokok dalam penelitian ini adalah, "Sejauhmana literasi informasi (information literacy) PNS Tenaga Pendidik di Provinsi Jambi, Bengkulu, Kepulauan Bangka-Belitung dan DKI Jakarta?"

Penelitian ini secara umum bertujuan untuk melakukan pemetaan tingkat literasi informasi (information literacy) tenaga pendidik di lingkungan PNS di Provinsi Jambi, Bengkulu, Kepulauan BangkaBelitung, dan DKI Jakarta.

Kegunaan penelitian ini adalah sebagai suatu policy research, dan diharapkan dapat menjadi masukan berharga bagi pemerintah dalam pembuatan kebijakankebijakan tentang akses informasi dan komunikasi khususnya, dan kebijakankebijakan tentang pengembangan masyarakat informasi umumnya.

Sebagai suatu scientific research, hasil penelitian diharapkan dapat menghasilkan penjelasan baru tentang konsep teoretik literasi informasi (Information literacy) dalam studi komunikasi. 
Penelitian dilaksanakan di Provinsi Jambi, Provinsi Bangka Belitung, Provinsi Bengkulu, dan Provinsi DKI Jakarta. Penelitian dilaksanakan selama 6 (enam) bulan dari bulan Januari sampai dengan bulan Juni Tahun 2009.

\section{LANDASAN KONSEP}

\section{Literasi Informasi}

\section{Menurut Asosiasi Pekerja Informasi Sekolah Indonesia (APISI) "Literasi informasi adalah seperangkat keterampilan untuk mendapatkan jalan keluar dari suatu masalah yang ada. Keterampilan ini mencakup keterampilan mengidentifikasi masalah, mencari informasi, menyortir, menyusun, memanfaatkan, mengomunikasikan, dan mengevaluasi hasil jawaban dari pertanyaan atau masalah yang dihadapi tadi" (rettamd.blogspot.com).}

Sementara merujuk pada pendapat Jeremy J. Shapiro and Shelley K. Hughes, "Information Literacy as a Liberal Art", ( www.fctel.uncc.edu) terdapat tujuh dimensi literasi informasi yang dapat diidentifikasi:

1. Tool literacy, atau kemampuan memahami dan menggunakan alat teknologi informasi secara praktik dan konseptual, termasuk software, hardware, dan multimedia, yang relevan dengan pendidikan dan wilayah pekerjaan dan profesional sehingga membuat individu eksis. Ini termasuk pula dasar-dasar aplikasi komputer dan jaringan seperti konsep mendasar dari algoritma, struktur data dan protokol, dan topologi jaringan.

2. Resource literacy, atau kemampuan memahami bentuk, format, lokasi, dan metode akses terhadap sumber-sumber informasi khususnya mengembangkan jaringan sumber-sumber informasi setiap hari.

3. Social-structural literacy, atau mengetahui apa dan bagaimana informasi diproduksi sosial. Ini berarti mengetahui tentang bagaimana informasi layak masuk ke dalam kehidupan suatu kelompok; jaringan institusi dan sosial seperti universitas, perpustakaan, komunitas peneliti, korporasi, agensi pemerintah, kelompok-kelompok komunitas, sehingga menciptakan dan mengorganisasi informasi dan pengetahuan; dan proses sosial secara general, sehingga antarkelompok dapat melakukan share.

4. Research literacy, atau kemampuan memahami dan menggunakan alat TI secara dasar yang relevan dengan aktivitas/pekerjaan pelajar dan dunia riset saat ini.

5. Publishing literacy, atau kemampuan memformat dan mem-publish riset dan idea secara elektronik, dalam bentuk secara tekstual dan multimedia (termasuk via World Wide Web, electronic mail dan daftar distribusi, dan CD-ROMs), memperkenalkan mereka ke dalam publik elektronik secara nyata dan komunitas elektronik.

6. Emerging technology literacy, atau kemampuan mudah beradaptasi, mengerti, menilai dan membuat secara kontinyu penemuan/inovasi dalam teknologi informasi.

7. Critical literacy, atau kemampuan melakukan penilaian secara kritis intelektual, human, dan kekuatan dan kelemahan sosial, potensi-potensi dan batasan-batasan, keuntungan dan kerugian teknologi informasi.

Dalam penelitian ini, dari tujuh dimensi literasi informasi tersebut, tingkat literasi PNS Tenaga pendidik dilihat dari lima dimensi, yaitu Tool literacy, Resource literacy, Publishing literacy, Emerging technology literacy, Critical literacy.

\section{Kerangka Penelitian}

Berdasarkan permasalahan penelitian, maka kerangka penelitian ini dapat digambarkan sebagai berikut: 
Gambar 1.

Kerangka Penelitian

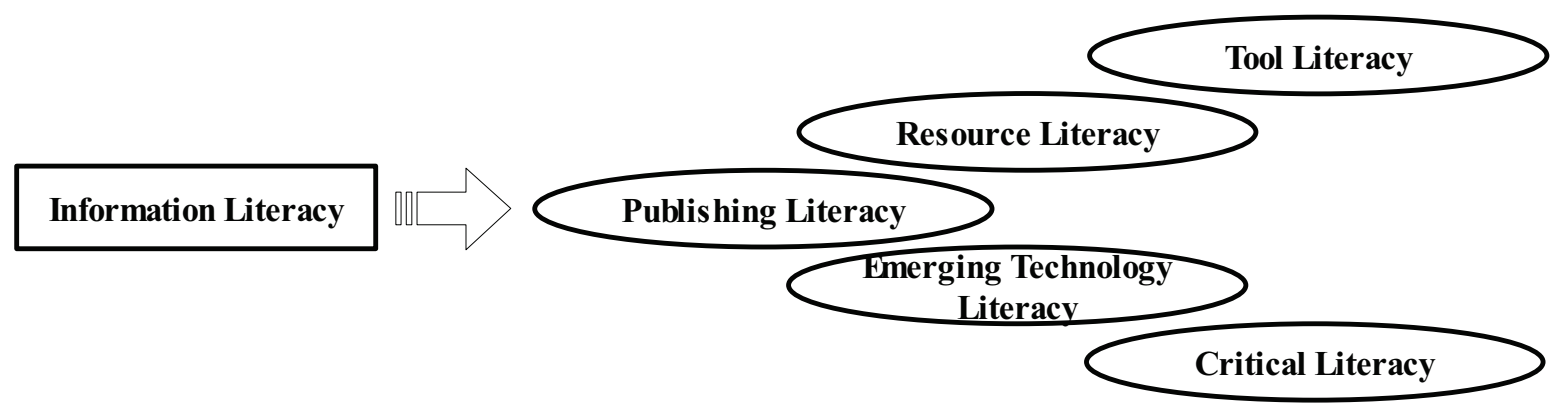

\section{Batasan Istilah}

1. Literasi Informasi (Information Literacy) adalah kemampuan dalam mengakses, mengevaluasi, dan menggunakan informasi dalam beraneka ragam format seperti buku, koran, video, CD-ROM atau Web, yang dilihat dari lima dimensi yaitu Tool literacy, Resource literacy, Publishing literacy, Emerging technology literacy, Critical literacy.

2. Pengajar atau guru atau pendidik pada pendidikan anak usia dini jalur sekolah atau pendidikan formal, pendidikan dasar, dan pendidikan menengah. Guru-guru seperti ini harus memiliki semacam kualifikasi formal. (id.wikipedia.org.).
Guru adalah profesi. Dalam penelitian ini pengertian 'guru' dibatasi pada pendidik atau pengajar pada pendidikan formal pada tingkat SMU yang berada di Provinsi Jambi, Bengkulu, Kepulauan Bangka Belitung, dan DKI Jakarta.

Berdasarkan latar belakang penelitian dan tujuan dari penelitian ini, yaitu untuk mendapatkan gambaran mengenai tingkat literasi informasi (Information Literacy) pada guru Sekolah Menengah Umum (SMU) di Provinsi Jambi, Bengkulu, Kepulauan Bangka Belitung, dan DKI Jakarta, maka untuk lebih jelasnya arah penelitian ini dapat digambarkan dalam matrik penelitian sebagai berikut;

Gambar 2

Operasional Variabel

\begin{tabular}{|c|c|c|}
\hline Variabel & Indikator & Skala \\
\hline $\begin{array}{l}\text { Literasi } \\
\text { Informasi } \\
\text { (Information } \\
\text { Literacy) }\end{array}$ & $\begin{array}{l}\text { 1.Tool literacy } \\
\text { Kemampuan memahami dan menggunakan alat teknologi informasi secara } \\
\text { praktik dan konseptual } \\
\text { 2.Resource literacy } \\
\text { Kemampuan memahami bentuk, format, dan metode akses terhadap sumber- } \\
\text { sumber informasi } \\
\text { 3.Publishing literacy } \\
\text { Kemampuan memformat dan mempublish riset dan idea secara elektronik, } \\
\text { dalam bentuk secara tekstual dan multimedia (termasuk via World Wide Web, } \\
\text { electronic mail dan daftar distribusi, dan CD-ROMs } \\
\text { 4.Emerging technology literacy } \\
\text { Kemampuan mudah beradaptasi, mengerti, menilai dan membuat secara } \\
\text { kontinyu penemuan/inovasi dalam teknologi informasi } \\
\text { 5.Critical literacy } \\
\text { Kemampuan melakukan penilaian secara kritis intelektual, human, dan } \\
\text { kekuatan dan kelemahan sosial, potensi-potensi dan batasan-batasan, } \\
\text { keuntungan dan kerugian teknologi informasi }\end{array}$ & Ordinal \\
\hline
\end{tabular}




\section{METODE PENELITIAN}

Penelitian ini bersifat deskriptif, yakni hanya sebatas menjelaskan satu atau lebih mengenai suatu fenomena, dalam hal ini fenomena literasi informasi dan tenaga pendidik di lingkungan PNS. Metode yang digunakan yaitu survei sampel dari suatu populasi, yakni para tenaga pendidik (guru) PNS di Provinsi Jambi, Kepulauan Bangka Belitung, Bengkulu dan DKI Jakarta. Populasi tenaga pendidik dimaksud mengacu pada dokumentasi Direktorat Jenderal Peningkatan Mutu Pendidik dan Tenaga Kependidikan Departemen Pendidikan Nasional (www.nuptk.info). Penentuan area sampel di setiap Provinsi dilakukan dengan teknik random sampling. Area sampel itu terdiri dari: Provinsi Jambi (Pemkot Jambi dan Pemkab Batang Hari), Provinsi Kepulauan Bangka Belitung (Pemkot Pangkal Pinang dan Pemkab Belitung), Provinsi Bengkulu (Pemkot Bengkulu dan Pemkab Rejang Lebong), Provinsi DKI Jakarta (Pemkot Jakarta Timur dan Pemkab Kepulauan Seribu).

Populasi di area sampel sebanyak 70.222 guru PNS. Penentuan sampel penelitian menggunakan teknik sampel proporsional berstrata (Stratified Proportional Simple Random Sampling), populasi 70.222 orang $(\mathbf{N})$. Jumlah sampel penelitian ditetapkan berdasarkan quota sejumlah 400 (Sz), yang didistribusikan ke setiap provinsi (pemkot dan pemkab) lokasi penelitian dengan menggunakan rumus $\boldsymbol{n} / \mathbf{N} \boldsymbol{x} \boldsymbol{S} \boldsymbol{z}$.

Data primer kuantitatif penelitian ini yaitu jawaban responden atas jawaban dari sejumlah pertanyaan yang sebelumnya telah disusun ke dalam kuesioner. Pengumpulan datanya dilakukan dengan menyebarkan angket yang proses pengisiannya ditunggu oleh petugas yang terlatih. Pengolahan dan analisis data primer kuantitatif dilakukan dengan bantuan komputer yang menggunakan Program SPSS 12,0 For Windows. Analisis data diorientasikan pada central of tendency, disperse dan asosiasi simetris.

\section{HASIL PENELITIAN DAN PEMBAHASAN}

\section{Karakteristik Responden}

Karakteristik responden dalam penelitian ini mencakup jenis kelamin responden, usia responden, pendidikan terakhir responden, jabatan fungsional, jabatan rangkap responden, masa kerja PNS, bidang ilmu/mata pelajaran yang diajarkan responden, ketersediaan media/alat TIK di lembaga pendidikan, kepemilikan media/alat TIK secara pribadi, serta aktivitas komunikasi melalui internet dalam dua minggu terakhir.

Responden berjenis kelamin laki-laki di wilayah Jambi sebanyak 46,1\% dan responden perempuan 53,9\%. Di Bengkulu proporsi responden wanita sebanyak 53,3\% dan laki-laki 46,7\%. Sedang di Jakarta, wanita dengan proporsi $57,8 \%$ dan laki-laki $42,2 \%$.

Tabel 1

\section{Responden Menurut Kategori MDG's}

\begin{tabular}{|c|c|c|c|c|c|c|c|c|}
\hline \multirow{3}{*}{ Kategori MDGs } & \multicolumn{8}{|c|}{ Lokasi Penelitian } \\
\hline & \multicolumn{2}{|c|}{ Jambi } & \multicolumn{2}{|c|}{ Babel } & \multicolumn{2}{|c|}{ Bengkulu } & \multicolumn{2}{|c|}{ Jakarta } \\
\hline & $\mathbf{F}$ & $\%$ & $\mathbf{F}$ & $\%$ & $\mathbf{F}$ & $\%$ & $\mathbf{F}$ & $\%$ \\
\hline Veteran $($ lahir <1946) & 3 & 3.4 & - & - & - & - & - & - \\
\hline Baby Boomers (lahir $1946-1964$ ) & 36 & 40.4 & 7 & 19.4 & 13 & 28.9 & 137 & 59.6 \\
\hline Xers (lahir 1965 - 1982) & 44 & 49.4 & 23 & 63.9 & 28 & 62.2 & 80 & 34,8 \\
\hline Millenial (lahir > 1982) & 6 & 6.7 & 6 & 16.7 & 4 & 8.9 & 13 & 5.7 \\
\hline Total & 89 & 100 & 36 & 100 & 45 & 100 & 230 & 100 \\
\hline
\end{tabular}

Sumber: Hasil Pengolahan Data BPPKI Jakarta, 2009 
Sementara, di wilayah Babel, proporsi responden laki-laki jauh lebih besar $(66.7 \%)$ jika dibandingkan dengan proporsi responden perempuannya $(33.3 \%)$.

Berdasarkan kategori MDG's, data tabel 1 memperlihatkan kecenderungan yang relatif sama. Di ketiga lokasi, yaitu Jambi, Babel dan Bengkulu, kebanyakan responden berkategori Xers, yakni yang lahir antara tahun 1965 - 1982. Pola distribusi yang kontras terjadi di Jakarta, di lokasi ini, responden yang dominan, yaitu responden yang berkategori Baby Boomers, yakni dengan proporsi $59,6 \%$.

Dari tingkat pendidikan terakhir responden di empat lokasi, proporsi responden dengan tingkat pendidikan terakhir "Sarjana" merupakan yang terbanyak dibandingkan dengan tingkat pendidikan lainnya. Sementara sebaran level pendidikan lainnya, juga terlihat relatif sama polanya mulai dari Diploma, Pasca Sarjana, dan SLTA. Pada jabatan fungsional responden, menunjukkan adanya kesamaan pada proporsi distribusi responden dengan jabatan "Guru Pembina" di empat wilayah, dengan menempatkan jabatan fungsional Guru Pembina pada posisi teratas.

Selanjutnya untuk jabatan rangkap responden, memperlihatkan jabatan rangkap sebagai "Wali kelas" merupakan yang paling banyak disandang oleh responden di empat lokasi, jabatan rangkap lainnya memiliki persentase kurang signifikan pada jabatan Wakil Kepala Sekolah, Kepala Sekolah, dan Kasubbag Tata Usaha. .

Mengenai masa kerja responden sebagai PNS, menunjukkan terdapat sedikit kesamaan pada responden di Jambi dan Babel, di mana responden dengan masa kerja kurang dari 5 tahun menduduki urutan teratas, yaitu di Jambi 21,3\% dan di Babel 52,8\%. Di Bengkulu, posisi teratas $(24,4 \%)$ ditempati oleh responden dengan masa kerja 16-20 tahun, sedangkan di DKI Jakarta dengan proporsi $35,7 \%$, posisi teratasnya ditempati oleh responden dengan masa kerja 21-26 tahun.

Tabel 2

Responden Menurut Jabatan Fungsional

\begin{tabular}{|l|r|r|r|r|r|r|r|}
\hline \multirow{3}{*}{ Jabatan Fungsional } & \multicolumn{7}{|c|}{ Lokasi Penelitian } \\
\cline { 2 - 9 } & \multicolumn{1}{|c|}{ Jambi } & \multicolumn{1}{|c|}{ Babel } & \multicolumn{1}{c|}{ Bengkulu } & Jakarta \\
\cline { 2 - 9 } & \multicolumn{1}{|c|}{ F } & \multicolumn{1}{c|}{ \% } & \multicolumn{1}{c|}{ F } & \multicolumn{1}{c|}{ \% } & \multicolumn{1}{c|}{ F } & \multicolumn{1}{c|}{ \% } & \multicolumn{1}{c|}{ F } \\
\hline Guru Pratama & 2 & 2.2 & 8 & 22.2 & 2 & 4.4 & 7 \\
\hline Guru Pratama Tk. I & 1 & 1.1 & - & - & - & - & 1 \\
\hline Guru Muda & 2 & 2.2 & 4 & 11.1 & 2 & 4.4 & 4 \\
\hline Guru Muda Tk. I & - & - & 7 & 19.4 & 3 & 6.7 & 8 \\
\hline Guru Madya & 22 & 24.7 & 2 & 5.6 & 4 & 8.9 & 19 \\
\hline Guru Madya Tk. I & 2 & 2.2 & 2 & 5.6 & 2 & 4.4 & 8 \\
\hline Guru Dewasa & 10 & 11.2 & 1 & 2.8 & 1 & 2.2 & 19 \\
\hline Guru Dewasa Tk.I & 4 & 4.5 & 3 & 8.3 & 7 & 15.6 & 35 \\
\hline Guru Pembina & 43 & 48.3 & 8 & 22.2 & 22 & 48.9 & 108 \\
\hline Guru Pembina Tk. I & 2 & 2.2 & 1 & 2.8 & 1 & 2.2 & 16 \\
\hline Guru Utama Muda & 1 & 1.1 & - & - & 1 & 2.2 & 1 \\
\hline Guru Pembina Utama & - & - & - & - & - & - & 1 \\
\hline Total & $\mathbf{8 9}$ & $\mathbf{1 0 0}$ & $\mathbf{3 6}$ & $\mathbf{1 0 0}$ & $\mathbf{4 5}$ & $\mathbf{1 0 0}$ & $\mathbf{2 2 7}$ \\
\hline
\end{tabular}

Sumber: Hasil Pengolahan Data BPPKI Jakarta, 2009 
Selanjutnya berkaitan dengan bidang ilmu/mata pelajaran yang diajarkannya, adanya kesamaan di empat lokasi yang menempatkan bidang/mata pelajaran Ilmu Pasti/IPA pada posisi teratas. Pola distribusi yang sama juga terjadi pada jumlah responden yang mengajar Ilmu Sosial, yang berdasarkan proporsinya menempati urutan kedua. Hal ini terjadi di tiga lokasi, yaitu Jambi, Bengkulu, dan DKI Jakarta.

Dilihat dari ketersediaan media/alat TIK di lembaga pendidikan di empat lokasi itu, proporsi ketersediaan Komputer di Jambi dan DKI Jakarta menempati urutan teratas. Kondisi ini berlawanan dengan fakta yang terjadi di Babel dan Bengkulu yang justru menempatkan telepon sebagai media TIK yang ketersediaannya paling banyak dimiliki responden. Sedangkan di empat lokasi, media Internet menduduki urutan ketiga.

Sementara itu, dilihat dari pola distribusi responden yang tidak memiliki media TIK, di Jambi responden yang tidak memiliki e-mail pribadi menduduki urutan teratas, disusul Bengkulu, DKI Jakarta, kemudian Babel. Selain itu, Jambi juga merupakan lokasi di mana respondennya paling banyak yang tidak memiliki internet pribadi, diikuti Bengkulu, Babel, dan DKI Jakarta.
Data pada Tabel 3 memperlihatkan adanya sedikit kesamaan dalam pola distribusi responden menurut aktivitas komunikasinya melalui internet dalam dua minggu terakhir. Kesamaan itu terjadi di Jambi dan DKI Jakarta, di mana proporsi terbanyak terdapat pada responden yang menjawab 1 kali.

\section{Literasi Informasi Responden}

1. Kemampuan menggunakan peralatan (tools literacy).

Hal-hal yang menandai aspek kemampuan pertama dari responden, yaitu kemampuan menggunakan peralatan (tools literacy).

Dari jenis komponen-komponen ketika responden menggunakan komputer yang meliputi printer, scanner, monitor, storage media (disket, flashdisk, CDR, CDRW), Unit Power Supply, kamera digital, handphone, webcam, dan stroom listrik, dari data yang diperoleh, diketahui bahwa lebih dari tiga perempat responden terkait jenis komponen yang harus terpenuhi dalam bekerja dengan menggunakan komputer, di mana proporsi terbesar pertama $(97,2 \%)$ di Prov. Babel terkait jenis komponen stroom

Tabel 3

\section{Responden Menurut Aktivitas Komunikasi Melalui Internet} Dalam Dua Minggu Terakhir

\begin{tabular}{|c|c|c|c|c|c|c|c|}
\hline \multirow{3}{*}{ Aktivitas } & \multicolumn{7}{|c|}{ Lokasi Penelitian } \\
\hline & \multicolumn{2}{|c|}{ Jambi } & \multicolumn{2}{|c|}{ Babel } & \multicolumn{2}{|c|}{ Bengkulu } & \multirow{2}{*}{$\begin{array}{c}\text { Jakarta } \\
\text { F }\end{array}$} \\
\hline & $\mathbf{F}$ & $\%$ & $\mathbf{F}$ & $\%$ & $\mathbf{F}$ & $\%$ & \\
\hline $1 \mathrm{kali}$ & 34 & 38.2 & 5 & 13.9 & 9 & 20.0 & 48 \\
\hline 2 kali & 8 & 9.0 & 4 & 11.1 & 6 & 13.3 & 42 \\
\hline 3 kali & 5 & 5.6 & 3 & 8.3 & 4 & 8.9 & 22 \\
\hline 4 kali & 6 & 6.7 & 2 & 5.6 & 3 & 6.7 & 22 \\
\hline 5 kali & 9 & 10.1 & - & - & 1 & 2.2 & 16 \\
\hline 6 kali & 1 & 1.1 & 5 & 13.9 & 4 & 8.9 & 8 \\
\hline 7 kali & 6 & 6.7 & 11 & 30.6 & 11 & 24.4 & 21 \\
\hline$>7$ kali & - & - & 1 & 2.8 & - & - & 4 \\
\hline Tidak pernah & 20 & 22.5 & 5 & 13.9 & 7 & 15.6 & 47 \\
\hline Total & 89 & 100 & 36 & 100 & 45 & 100 & 230 \\
\hline
\end{tabular}

Sumber: Hasil Pengolahan Data BPPKI Jakarta, 2009 
listrik, sedangkan di Prov. DKI Jakarta (85,7\%), Prov. Bengkulu $(84,4 \%)$ dan Prov. Jambi $(78,7 \%)$ ketiganya menyangkut jenis komponen yang sama, yakni monitor. Sementara pada penggunaan komponen handphone, webcam, dan kamera digital ketika menggunakan komputer persentasenya kecil pada responden di empat wilayah.

Sementara pada tingkat kemampuan
ideal yang harus dipenuhi dalam pengoperasionalan komputer yang meliputi tujuh karakteristik: menyalakan komputer, membuat dokumen, membuka dokumen, mengedit dokumen, menggandakan atau memindahkan dokumen, mengoperasikan aplikasi, dan mematikan komputer sesuai prosedur, memperlihatkan di empat lokasi penelitian, penguasaan responden lebih dominan pada proporsi terbesar pertama $(100 \%)$ di Prov. Babel untuk kemampuan menyalakan komputer, mengoperasikan aplikasi dan mematikan komputer sesuai prosedur, sedangkan di Prov. Jambi (91\%) terkait kemampuan mematikan komputer sesuai prosedur, di Prov. Jakarta (90\%) menyangkut kemampuan menyalakan komputer dan mematikan komputer sesuai prosedur, dan di Prov. Bengkulu (80\%) untuk kemampuan mematikan komputer sesuai prosedur.

Pada aspek tingkat keseringan menggunakan bantuan orang lain dalam melakukan hal-hal ideal yang harus dipenuhi dalam pengoperasionalisasian komputer yang meliputi karakteristik: menyalakan komputer, membuat dan membuka password, membuat dokumen, membuka dokumen, mengedit dokumen, menggandakan dan memindahkan dokumen, mengoperasikan aplikasi perkantoran, Ms Word, Excel, mengoperasikan aplikasi database, dan mematikan komputer sesuai prosedur, diketahui responden di empat wilayah lebih dominan berpendapat tidak pernah menggunakan bantuan orang lain dibandingkan pendapat lainnya dalam mengoperasikan komputer. Di mana proporsi terbesar pertama $(88,9 \%)$ terdapat di Prov. Babel untuk kemampuan menyalakan komputer, sedangkan di Prov. Jakarta $(71,3 \%)$ dan Prov. Bengkulu $(71,1 \%)$ terkait sama, yakni kemampuan mematikan komputer sesuai prosedur, serta di Prov. Jambi $(69,7 \%)$ menyangkut kemampuan menyalakan komputer.

\section{Kemampuan sumber (resource literacy)}

Masuk ke aspek kedua yang menandai tingkat literasi informasi responden, yaitu kemampuan sumber (resource literacy). Kemampuan ini diukur dari hal-hal yang dijabarkan berikut :

\section{a. Sumber Informasi}

Kemampuan dalam menggunakan komponen-komponen sumber Informasi (komputer, media storage, kamera digital, handphone, dan webcam) yang secara ideal harus terpenuhi dalam bekerja dengan menggunakan komputer untuk keperluan akses informasi pada empat lokasi, lebih dominan pertama $(97,2 \%)$ terdapat di Prov. Babel terkait komponen sumber informasi komputer. Komponen yang sama juga ditemui di Prov. DKI Jakarta $(87,8 \%)$, di Prov. Jambi (82\%) dan Prov. Bengkulu (77,8\%). Untuk urutan kedua pada responden di tiga wilayah Provinsi Jambi, Bangka Belitung, dan Bengkulu, sumber informasi yang dikuasai adalah media storage dengan persentase lebih dari $50 \%$. Kecuali di DKI Jakarta sumber informasi kedua setelah komputer yang dikuasai adalah handphone (53,5\%).

Mengenai tingkat keseringan menggunakan bantuan orang lain dalam bekerja dengan memakai komputer yang memanfaatkan sumber-sumber informasi untuk keperluan akses informasi, responden lebih dominan berpendapat tidak pernah dan jarang dibandingkan pendapat lainnya terkait menggunakan bantuan orang lain tersebut dalam bekerja pada empat lokasi dimaksud, di mana proporsi terbesar pertama $(55,9 \%)$ terdapat di Prov. Babel dengan pendapat responden tidak pernah menyangkut sumber informasi handphone, sedangkan pendapat yang sama juga dijumpai di Prov. DKI Jakarta (49,6\%).

\section{b. Metode akses}

Metode-metode akses informasi yang secara ideal harus terpenuhi dalam bekerja dengan menggunakan komputer 
Tabel 4

Metode-Metode Akses Informasi Yang Secara Ideal Harus Terpenuhi
Dalam Bekerja Dengan Menggunakan Komputer

\begin{tabular}{|c|c|c|c|c|c|c|c|c|c|c|}
\hline \multirow{2}{*}{$\begin{array}{c}\text { Lokasi } \\
\text { Penelitian }\end{array}$} & \multirow{2}{*}{ Metode akses informasi } & \multicolumn{2}{|c|}{ Tidak ideal } & \multicolumn{2}{|c|}{ Kurang ideal } & \multicolumn{2}{|c|}{$\begin{array}{c}\text { Cukup } \\
\text { ideal }\end{array}$} & \multicolumn{2}{|c|}{$\begin{array}{c}\text { Sangat } \\
\text { ideal }\end{array}$} & \multirow{2}{*}{$\begin{array}{c}\text { Tot } \\
\text { al }\end{array}$} \\
\hline & & $\mathbf{F}$ & $\%$ & $\mathbf{F}$ & $\%$ & $\mathbf{F}$ & $\%$ & $\mathbf{F}$ & $\%$ & \\
\hline \multirow{4}{*}{ Jambi } & Memindai/scanning dokumen & 7 & 7.9 & 3 & 3.4 & 37 & 41.6 & 42 & 47.2 & 89 \\
\hline & Mendownload file dari internet & 9 & 10.1 & 2 & 2.2 & 31 & 34.8 & 47 & 52.8 & 89 \\
\hline & Memfoto dokumen atau objek & 9 & 10.1 & 5 & 5.6 & 37 & 41.6 & 38 & 42.7 & 89 \\
\hline & Merekam audio atau video & 9 & 10.1 & 4 & 4.5 & 37 & 41.6 & 39 & 43.8 & 89 \\
\hline \multirow{4}{*}{ Babel } & Memindai/scanning dokumen & - & - & 1 & 2.8 & 8 & 22.2 & 27 & 75.0 & 36 \\
\hline & Mendownload file dari internet & - & - & - & - & 7 & 19.4 & 29 & 80.6 & 36 \\
\hline & Memfoto dokumen atau objek & - & - & 1 & 2.8 & 14 & 38.9 & 21 & 58.3 & 36 \\
\hline & Merekam audio atau video & - & - & - & - & 11 & 30.6 & 25 & 69.4 & 36 \\
\hline \multirow{4}{*}{ Bengkulu } & Memindai/scanning dokumen & 5 & 11.1 & 5 & 11.1 & 15 & 33.3 & 20 & 44.4 & 45 \\
\hline & Mendownload file dari internet & - & - & - & - & 22 & 48.9 & 23 & 51.1 & 45 \\
\hline & Memfoto dokumen atau objek & - & - & 7 & 15.6 & 25 & 55.6 & 13 & 28.9 & 45 \\
\hline & Merekam audio atau video & 1 & 2.2 & 4 & 8.9 & 27 & 60.0 & 13 & 28.9 & 45 \\
\hline \multirow{4}{*}{ Jakarta } & Memindai/scanning dokumen & 3 & 1.3 & 9 & 3.9 & 94 & 40.9 & 124 & 53.9 & 230 \\
\hline & Mendownload file dari internet & 1 & .4 & 6 & 2.6 & 74 & 32.2 & 149 & 64.8 & 230 \\
\hline & Memfoto dokumen atau objek & 1 & .4 & 21 & 9.1 & 101 & 43.9 & 107 & 46.5 & 230 \\
\hline & Merekam audio atau video & 4 & 1.7 & 17 & 7.4 & 111 & 48.3 & 98 & 42.6 & 230 \\
\hline
\end{tabular}

Sumber: Hasil Pengolahan Data BPPKI Jakarta, 2009

yang meliputi kemampuan: memindai/ scanning dokumen, men-download file dari internet, mem-foto dokumen atau objek, dan merekam audio atau video, yaitu, diketahui responden di empat lokasi dominan pertama $(80,6 \%)$ terdapat di Prov. Babel berkaitan metode akses informasi men-download file dari internet, sementara metode akses yang sama terjadi di Prov. DKI Jakarta $(64,8 \%)$ dan di Prov. Jambi (52,8\%), namun berbeda di Prov. Bengkulu (60\%) responden berpendapat cukup ideal menyangkut metode akses informasi merekam audio atau video.

Mengenai tingkat keseringan menggunakan bantuan orang lain dalam bekerja dengan memakai komputer yang memerlukan metode-metode akses informasi meliputi memindai/scanning dokumen, men-download file dari internet, mem-foto dokumen atau objek, dan merekam audio atau video pada empat lokasi, responden lebih dominan berpendapat jarang dibandingkan pendapat lainnya. Namun proporsi terbesar pertama (44,4\%) terdapat di Prov. Babel dengan responden berpendapat tidak pernah untuk metode akses informasi men-download file dari internet dan mem-foto dokumen atau objek, sedangkan responden berpendapat jarang $(40,9 \%)$ di Prov. Jakarta terkait metode akses informasi mem-foto dokumen atau objek, sama halnya di Prov. Jambi namun menyangkut metode akses informasi merekam audio atau video (39,3\%) sangat sering di Prov. Bengkulu untuk metode akses informasi memindai/scanning dokumen.

3. Kemampuan mempublikasi secara elektronik (publishing literacy)

Berikutnya aspek yang juga menandai tingkat literasi informasi responden, yaitu kemampuan mempublikasi secara elektronik (publishing literacy). 


\section{Tabel 5}

\section{Kemampuan Yang Secara Ideal Harus Terpenuhi Dalam Bekerja Dengan Menggunakan} Komputer Untuk Keperluan Publikasi Elektronik

\begin{tabular}{|c|c|c|c|c|c|c|c|c|c|c|}
\hline \multirow{2}{*}{$\begin{array}{l}\text { Lokasi } \\
\text { Penelitian }\end{array}$} & \multirow{2}{*}{ Kemampuan } & \multicolumn{2}{|c|}{$\begin{array}{l}\text { Tidak } \\
\text { menguasai }\end{array}$} & \multicolumn{2}{|c|}{$\begin{array}{l}\text { Kurang } \\
\text { menguasai }\end{array}$} & \multicolumn{2}{|c|}{$\begin{array}{l}\text { Cukup } \\
\text { menguasai }\end{array}$} & \multicolumn{2}{|c|}{$\begin{array}{c}\text { Sangat } \\
\text { menguasai }\end{array}$} & \multirow{2}{*}{$\begin{array}{c}\text { Total } \\
\mathrm{F}\end{array}$} \\
\hline & & $\mathrm{F}$ & $\%$ & $\mathrm{~F}$ & $\%$ & $F$ & $\%$ & $F$ & $\%$ & \\
\hline \multirow{4}{*}{ Jambi } & $\begin{array}{l}\text { Menyimpan dokumen dalam format } \\
\text { file sesuai kebutuhan }\end{array}$ & 6 & 6.7 & 3 & 3.4 & 25 & 28.1 & 55 & 61.8 & 89 \\
\hline & $\begin{array}{l}\text { Meng-upload dokumen ke internet } \\
\text { (situs, blog, dll) }\end{array}$ & 7 & 7.9 & 10 & 11.2 & 35 & 39.3 & 37 & 41.6 & 89 \\
\hline & $\begin{array}{l}\text { Menyimpan dokumen melalui CD } \\
\text { ROM }\end{array}$ & 7 & 7.9 & 5 & 5.6 & 32 & 36.0 & 45 & 50.6 & 89 \\
\hline & $\begin{array}{l}\text { Menggandakan dokumen melalui } \\
\text { CD ROM }\end{array}$ & 7 & 7.9 & 6 & 6.7 & 35 & 39.3 & 41 & 46.1 & 89 \\
\hline \multirow{4}{*}{ Babel } & $\begin{array}{l}\text { Menyimpan dokumen dalam format } \\
\text { file sesuai kebutuhan }\end{array}$ & 1 & 2.8 & - & - & 7 & 19.4 & 28 & 77.8 & 36 \\
\hline & $\begin{array}{l}\text { Meng-upload dokumen ke internet } \\
\text { (situs, blog, dll) }\end{array}$ & 1 & 2.8 & 8 & 22.2 & 8 & 22.2 & 19 & 52.8 & 36 \\
\hline & $\begin{array}{l}\text { Menyimpan dokumen melalui CD } \\
\text { ROM }\end{array}$ & 1 & 2.8 & 6 & 16.7 & 1 & 2.8 & 28 & 77.8 & 36 \\
\hline & $\begin{array}{l}\text { Menggandakan dokumen melalui } \\
\text { CD ROM }\end{array}$ & 2 & 5.6 & - & - & 7 & 19.4 & 27 & 75.0 & 36 \\
\hline \multirow{4}{*}{ Bengkulu } & $\begin{array}{l}\text { Menyimpan dokumen dalam format } \\
\text { file sesuai kebutuhan }\end{array}$ & 1 & 2.2 & - & - & 16 & 35.6 & 28 & 62.2 & 45 \\
\hline & $\begin{array}{l}\text { Meng-upload dokumen ke internet } \\
\text { (situs, blog, dll) }\end{array}$ & - & - & 5 & 11.1 & 25 & 55.6 & 15 & 33.3 & 45 \\
\hline & $\begin{array}{l}\text { Menyimpan dokumen melalui CD } \\
\text { ROM }\end{array}$ & - & - & 2 & 4.4 & 26 & 57.8 & 17 & 37.8 & 45 \\
\hline & $\begin{array}{l}\text { Menggandakan dokumen melalui } \\
\text { CD ROM }\end{array}$ & 3 & 6.7 & 3 & 6.7 & 19 & 42.2 & 20 & 44.4 & 45 \\
\hline \multirow{4}{*}{ Jakarta } & $\begin{array}{l}\text { Menyimpan dokumen dalam format } \\
\text { file sesuai kebutuhan }\end{array}$ & 5 & 2.2 & 3 & 1.3 & 53 & 23.0 & 169 & 73.5 & 230 \\
\hline & $\begin{array}{l}\text { Meng-upload dokumen ke internet } \\
\text { (situs, blog, dll) }\end{array}$ & 4 & 1.7 & 5 & 2.2 & 81 & 35.2 & 140 & 60.9 & 230 \\
\hline & $\begin{array}{l}\text { Menyimpan dokumen melalui CD } \\
\text { ROM }\end{array}$ & 3 & 1.3 & 7 & 3.0 & 87 & 37.8 & 133 & 57.8 & 230 \\
\hline & $\begin{array}{l}\text { Menggandakan dokumen melalui } \\
\text { CD ROM }\end{array}$ & 3 & 1.3 & 12 & 5.2 & 82 & 35.7 & 133 & 57.8 & 230 \\
\hline
\end{tabular}

Sumber: Hasil Pengolahan Data BPPKI Jakarta, 2009

Berdasarkan data pada tabel 5, mengenai kemampuan yang secara ideal harus terpenuhi dalam bekerja dengan menggunakan komputer untuk keperluan publikasi elektronik pada empat lokasi dimaksud, di mana responden lebih dominan sangat menguasai dan cukup menguasai dibandingkan pendapat lainnya, namun proporsi terbesar pertama $(77,8 \%)$ terdapat di Prov. Babel dengan responden berpendapat sangat menguasai terkait kemampuan menyimpan dokumen dalam format file sesuai kebutuhan dan kemampuan menyimpan dokumen melalui CD ROM, sedangkan di
Prov. DKI Jakarta (73,5\%) menyangkut kemampuan menyimpan dokumen dalam format file sesuai kebutuhan, begitu juga kemampuan yang sama di Prov. Bengkulu $(62,2 \%)$, dan di Prov. Jambi $(61,8 \%)$ juga dengan kemampuan yang sama yakni menyimpan dokumen dalam format file sesuai kebutuhan.

Berdasarkan data penelitian, diketahui tingkat keseringan menggunakan bantuan orang lain dalam bekerja dengan memakai komputer yang berhubungan dengan aktivitas publikasi elektronik meliputi: meng-upload dokumen ke internet (situs, blog, dll.), 
mengirim dokumen ke orang lain atau mailing list, menyimpan dokumen ke internet (situs, blog, dll.), mengirim dokumen ke orang lain atau mailing list, menyimpan dokumen melalui CD ROM, menggandakan dokumen melalui CD ROM pada empat lokasi, di mana responden lebih dominan berpendapat jarang ketimbang pendapat lainnya, dengan proporsi terbesar pertama $(47,2 \%)$ terdapat di Provinsi.

4. Kemampuan beradaptasi dengan kemajuan teknologi (emerging technology literacy)

Indikator yang dipakai untuk mengukur kemampuan responden beradaptasi dengan kemajuan teknologi (emerging technology literacy) ditunjukkan sebagai berikut.

Aplikasi perkantoran yang ideal diterapkan di tempat kerja saat ini, meliputi aplikasi Microsoft office 3.0, Microsoft office 4.0, Microsoft office 95, Microsoft office 97, Microsoft ofice 2003, Microsoft office 2007, Microsoft office XP. Pengetahuan akan hal ini menjadi indikator kemampuan responden dalam beradaptasi dengan kemajuan teknologi. Jika diperhatikan dari hasil penelitian, secara umum responden di keempat provinsi tersebut telah mengetahui perkembangan teknologi informasi yang dalam penelitian ini ditandai dengan pengetahuannya akan aplikasi perkantoran yang ideal atau tidak ideal untuk digunakan di tempat kerja. Kesimpulan ini didapat dari beberapa alasan. Seperti di Provinsi Jambi, jenis aplikasi yang dipandang sangat ideal untuk dipakai saat ini, berturut-turut dari persentase terbesar, yaitu Microsoft Office XP (67,1\%), diikuti Microsoft Office 2007 (55,7\%) dan 2003 (49,4\%). Aplikasi-aplikasi 'office' ini tergolong jenis aplikasi yang up to date. Sementara aplikasi lain yang sudah lama muncul disetujui oleh sebagian besar responden (37,3\%-45,3\%) tidak ideal atau kurang ideal lagi digunakan.

Dari aspek tingkat keseringan responden menggunakan jenis aplikasi perkantoran tertentu di tempat kerja saat ini, meliputi aplikasi Microsoft office 3.0,
Microsoft office 4.0, Microsoft office 95, Microsoft office 97, Microsoft ofice 2003, Microsoft office 2007, Microsoft office XP, pilihan akan penggunaan aplikasi perkantoran tertentu juga menjadi indikator kemampuan responden dalam beradaptasi dengan kemajuan teknologi. Data menunjukkan, gejala di keempat provinsi cenderung sama, yaitu secara umum responden telah mengikuti dan mampu beradaptasi dengan perkembangan teknologi informasi dengan memilih menggunakan perkembangan aplikasi office yang terkini dan lebih update. Ditandai dengan penggunaan aplikasi Microsoft Office XP, 2007, dan 2003 dalam skala 'sangat sering' dengan persentase mencapai 47,9\%-78,1\%.

Dengan temuan data mengenai sistem operasi yang ideal digunakan di lingkungan kerja saat ini mencakup microsoft windows 95, microsoft windows 98, microsoft windows 2000, microsoft windows XP, dan microsoft windows vista, dapat terukur kemampuan adaptasi responden terhadap kemajuan teknologi. Secara umum responden di keempat provinsi tersebut telah mengetahui perkembangan teknologi informasi yang dalam penelitian ini ditandai dengan pengetahuannya akan sistem operasi yang ideal atau tidak ideal untuk digunakan di tempat kerja saat ini. Kesimpulan itu diperkuat oleh data kuantitatif di mana mayoritas (55,4\%-86,7\%) responden di keempat provinsi berpendapat sistem operasi terbaru, yaitu Microsoft Windows Vista dan Microsoft Windows XP merupakan sistem yang sangat ideal digunakan saat ini. Seperti di Provinsi Jambi, $67,9 \%$ responden berpendapat Microsoft Windows XP sangat ideal digunakan dan 55,4\% lainnya menyatakan Microsoft Windows Vista sangat ideal. Di ketiga provinsi lainnya, yaitu di Babel, Bengkulu, dan Jakarta gejalanya juga demikian dengan persentase untuk Windows XP lebih besar dari Windows Vista. Sementara itu, di Provinsi Babel dan Bengkulu, 41,9\%$66,7 \%$ responden menyatakan Windows 95 dan Windows 98 sudah tidak ideal lagi digunakan saat ini.

Dari hasil temuan mengenai tingkat keseringan menggunakan sistem operasi 
perkantoran di tempat kerja saat ini, sebagian besar $(35,8 \%-75 \%)$ responden di keempat provinsi telah menggunakan sistem operasi ter-update Microsoft Windows XP dan Microsoft Windows Vista dalam intensitas sangat sering. Namun tidak bisa diabaikan pula jumlah responden yang menggunakan Microsoft Windows 2000, Windows 98, atau Windows 95, entah karena lebih nyaman dan terbiasa menggunakan sistem operasi tersebut ketimbang yang lebih canggih, atau karena memang tidak mengetahui dan mengikuti perkembangan sistem operasi yang ada. Sementara itu, di Provinsi Bengkulu dan DKI Jakarta, selain gejala yang sama di dua provinsi sebelumnya di mana mayoritas responden menggunakan Microsoft Windows $\mathrm{XP}$, banyak yang sudah menggunakan Windows Vista, serta banyak pula yang masih menggunakan Windows 2000.

5. Kemampuan menyeleksi isi informasi secara kritis (critical literacy)

Menyangkut kemampuan responden dalam menyeleksi isi informasi secara kritis (critical literacy) seperti diuraikan di bawah ini.

Pada aspek kemampuan menyeleksi konten (isi) internet oleh pengguna, memperlihatkan, ternyata responden di keempat provinsi mayoritas memandang kemampuan menyeleksi konten (isi) internet perlu dimiliki oleh pengguna. Hal ini tampak dari nilai persentase di mana jawaban 'perlu' dimiliki menjadi jawaban terbanyak, baik di Provinsi Jambi (49,4\%), di Provinsi Babel $(55,6 \%)$, dan di Provinsi DKI Jakarta (53,9\%). Sementara di Provinsi Bengkulu, bahkan terdapat $48,9 \%$ responden yang berpendapat 'sangat perlu' terhadap kemampuan seleksi konten tersebut.

Sementara mengenai kemampuan seleksi konten yang sangat ideal dimiliki pengguna internet saat ini, menyangkut sumber download, unsur etika, aktualisasi konten, dan kapabilitas/kredibilitas konten, tampak bahwa keempat bidang/jenis seleksi tersebut, secara dominan dipandang responden di keempat provinsi, 'sangat ideal' untuk dimiliki oleh pengguna internet saat ini dengan persentase lebih rata-rata 55,9\%$62,8 \%$.

Dari tingkat keseringan menggunakan bantuan orang lain untuk melakukan aktivitas seleksi konten internet, menyangkut sumber download, unsur etika, aktualisasi konten, dan kapabilitas/kredibilitas konten, variasi jawaban responden terhadap hal ini cukup beragam dan kecenderungan di tiap provinsi berbeda-beda. Di Provinsi Jambi dan di Provinsi DKI Jakarta menunjukkan gejala yang sama, yaitu lebih banyak responden yang mengaku jarang dibantu orang lain dalam melakukan aktivitas seleksi konten internet, dengan persentase berturut-turut di kedua provinsi, yaitu $36 \%-39,5 \%$ dan $43 \%$ 46,6\%. Sementara di Provinsi Babel gejalanya mayoritas responden $(58,8 \%-65 \%)$ tidak pernah menggunakan bantuan orang lain dalam melakukan aktivitas seleksi konten internet, baik menyangkut unsur etika, aktualisasi konten maupun kapabilitas/kredibilitas konten. Dari gejalagejala di ketiga provinsi itu, maka dapat dikatakan bahwa secara umum responden telah mampu menyeleksi sendiri konten dari internet menyangkut keempat unsur tersebut.

Literasi Teknologi Informasi dan Komunikasi (TIK) atau ICT Literacy adalah kombinasi antara kemampuan intelektual, konsep mendasar dan keahlian terkini yang mengharuskan seseorang memiliki kemampuan dalam menggunakan teknologi informasi dan komunikasi secara efektif. Dalam maknanya yang paling luas, literacy (keberaksaraan) termasuk kemampuan untuk 'membaca' dan 'menulis' dengan terampil dalam pelbagai bentuk-bentuk pesan, terutama menimbang dominasi media elektronik berbasis citra.

Demikian halnya dengan literasi informasi atau Information Literacy, yaitu kemampuan dalam mengakses, mengevaluasi, dan menggunakan informasi dalam beraneka ragam format seperti buku, koran, video, CDROM atau Web. Kemampuan dalam memanfaatkan komputer menjadi salah satu indikator yang kini dinilai makin penting. Tentu ini saja juga tak cukup. Beragam faktor lain yang dinilai akan memengaruhi kesiapan masyarakat dalam menghadapi tantangan dan 
peluang yang berkembang dinamis.

Merujuk pada tujuh dimensi literasi informasi dari Jeremy J. Shapiro dan Shelley K. Hughes, tingkat literasi informasi pada tenaga pendidik di wilayah penelitian di delapan kota/kabupaten Provinsi Jambi, Bangka Belitung, Bengkulu, dan DKI Jakarta adalah sebagai berikut:

Kemampuan memahami dan menggunakan alat teknologi informasi secara praktik dan konseptual, termasuk software, hardware, dan multimedia (tools literacy), dapat dikatakan cukup memadai meskipun masih berada pada tingkat kemampuan standar.

Dari jenis komponen-komponen ketika responden menggunakan komputer yang meliputi printer, scanner, monitor, storage media (disket, flashdisk, CDR, CDRW), Unit Power Supply, Kamera digital, handphone, webcam, dan stroom listrik, sebagian besar responden berada pada kemampuan standar dalam penggunaan komputer, terlihat dari jenis komponen yang dikuasai dan sering digunakan terbatas pada komponen tertinggi pada printer, storage media, monitor, dan ketergantungan pada stroom listrik. Sementara pada penggunaan komponen dengan tingkat penggunaan lebih kompleks seperti kamera digital, handphone, webcam, scanner pada saat menggunakan komputer memiliki persentase yang kurang signifikan.

Tetapi pada tingkat kemampuan ideal yang harus dipenuhi dalam pengoperasionalan komputer yang meliputi tujuh karakteristik: menyalakan komputer, membuat dokumen, membuka dokumen, mengedit dokumen, menggandakan atau memindahkan dokumen, mengoperasikan aplikasi, dan mematikan komputer sesuai prosedur, secara umum responden memiliki kemampuan cukup memadai terlihat dari persentase jawaban yang cukup signifikan pada aspek tersebut.

Demikian halnya dalam aspek tingkat keseringan menggunakan bantuan orang lain dalam melakukan hal-hal ideal yang harus dipenuhi dalam pengoperasionalisasian komputer yang meliputi karakteristik: menyalakan komputer, membuat dan membuka password, membuat dokumen, membuka dokumen, mengedit dokumen, menggandakan dan memindahkan dokumen, mengoperasikan aplikasi perkantoran, MS Word, Excel, mengoperasikan aplikasi database, dan mematikan komputer sesuai prosedur. Kemandirian responden bisa dilihat dari rendahnya persentase menggunakan bantuan orang lain dalam menggunakan komputer.

Resource literacy, atau kemampuan memahami bentuk, format, lokasi, dan metode akses terhadap sumber-sumber informasi khususnya mengembangkan jaringan sumber-sumber informasi setiap hari, dapat dikatakan belum maksimal dalam arti masih terbatas pada pemanfaatan sedikit komponen sumber informasi serta metode pencarian/ akses informasi.

Kemampuan dalam menggunakan komponen-komponen sumber informasi (komputer, media storage, kamera digital, handphone, dan webcam) yang secara ideal harus terpenuhi dalam bekerja dengan menggunakan komputer untuk keperluan akses informasi, pada sebagian besar responden di empat wilayah untuk komponen komputer dan media storage cukup tinggi, sementara pada komponen lainnya kurang signifikan, kecuali di DKI Jakarta untuk komponen handphone.

Pada tingkat keseringan menggunakan bantuan orang lain dalam bekerja dengan memakai komputer yang memanfaatkan sumber-sumber informasi untuk keperluan akses informasi, cenderung rendah. Ini mengartikan tingkat kemandirian dalam operasional komputer sudah mandiri.

Metode-metode akses informasi yang secara ideal harus terpenuhi dalam bekerja dengan menggunakan komputer yang meliputi kemampuan: memindai/scanning dokumen, men-download file dari internet, mem-foto dokumen atau objek, dan merekam audio atau video. Persentase tertinggi pada sebagian responden adalah pada aspek mendownload file dari internet, kecuali di Provinsi Bengkulu justru persentase tertinggi berada pada aspek merekan audio atau video.

Sementara mengenai tingkat keseringan menggunakan bantuan orang lain 
dalam bekerja dengan memakai komputer yang memerlukan metode-metode akses informasi meliputi memindai/scanning dokumen, men-download file dari internet, mem-foto dokumen atau objek, dan merekam audio atau video, pada sebagian besar responden cenderung rendah kecuali pada Provinsi Bengkulu persentase menggunakan bantuan 'sangat sering' cukup tinggi yaitu pada memindai/scanning dokumen.

Publishing literacy, atau kemampuan memformat dan mem-publish riset dan idea secara elektronik, dalam bentuk secara tekstual dan multimedia (termasuk via World Wide Web, electronic mail dan daftar distribusi, dan CD-ROMs), memperkenalkan mereka ke dalam publik elektronik secara nyata dan komunitas elektronik, masih belum maksimal.

Mengenai kemampuan yang secara ideal harus terpenuhi dalam bekerja dengan menggunakan komputer untuk keperluan publikasi elektronik, ditemukan persentase cukup tinggi pada aspek-aspek terkait kemampuan menyimpan dokumen dalam format file sesuai kebutuhan dan kemampuan menyimpan dokumen melalui CD ROM.

Tingkat keseringan menggunakan bantuan orang lain dalam bekerja dengan memakai komputer yang berhubungan dengan aktivitas publikasi elektronik meliputi: meng-upload dokumen ke internet (situs, blog, dll.), mengirim dokumen ke orang lain atau mailing list, menyimpan dokumen ke internet (situs, blog, dll.), mengirim dokumen ke orang lain atau mailing list, menyimpan dokumen melalui CD ROM, menggandakan dokumen melalui CD ROM pada empat lokasi terbilang jarang, kecuali untuk responden di Provinsi Bengkulu 'sangat sering' pada menggandakan dokumen melalui CD ROM

Emerging technology literacy, atau kemampuan mudah beradaptasi, mengerti, menilai dan membuat secara kontinyu penemuan/inovasi dalam teknologi informasi, cukup baik.

Selanjutnya, menyangkut kemampuan responden beradaptasi dengan kemajuan teknologi (emerging technology literacy). Hal ini dilihat dari pengetahuan responden akan kemajuan teknologi dan keinginan serta kemampuannya untuk menggunakan teknologi terbaru. Kemajuan teknologi di sini diindikasikan dari aplikasi office dan sistem operasi yang dipakai. Hasil penelitian terhadap pendapat responden mengenai aplikasi perkantoran yang ideal diterapkan di tempat kerja saat ini. Dari data tersebut dapat diperoleh sebuah analisis bahwa responden di provinsi Jambi pada dasarnya telah mengetahui perkembangan aplikasi perkantoran yang semakin maju.

Dalam penggunaan aplikasi perkantoran yang ideal diterapkan di tempat kerja saat ini, meliputi aplikasi Microsoft office 3.0, Microsoft office 4.0, Microsoft office 95, Microsoft office 97, Microsoft office 2003, Microsoft office 2007, Microsoft office $\mathrm{XP}$, maupun sistem operasi yang ideal digunakan di lingkungan kerja saat ini mencakup microsoft windows 95, microsoft windows 98, microsoft windows 2000, microsoft windows XP, dan microsoft windows vista, di keempat provinsi telah menggunakan aplikasi perkantoran ter-update seperti Microsoft office XP dan Microsoft office 2007 maupun sistem operasi ter-update Microsoft Windows XP dan Microsoft Windows Vista dalam intensitas sangat sering. Namun tidak bisa diabaikan pula jumlah responden yang menggunakan Microsoft Windows 2000, Windows 98, atau Windows 95 masih ada. Dari aspek tingkat keseringan responden menggunakan jenis aplikasi perkantoran maupun sistem operasi yang ideal tertentu di tempat kerja saat ini pun masih berlangsung.

Critical literacy, atau kemampuan melakukan penilaian secara kritis intelektual, human, dan kekuatan dan kelemahan sosial, potensi-potensi dan batasan-batasan, keuntungan dan kerugian teknologi informasi dapat dikatakan cukup baik.

Pada aspek kemampuan menyeleksi konten (isi) internet oleh pengguna, memperlihatkan, ternyata responden di keempat provinsi mayoritas memandang kemampuan menyeleksi konten (isi) internet perlu dimiliki oleh pengguna.

Dari tingkat keseringan menggunakan bantuan orang lain untuk melakukan aktivitas 
seleksi konten internet, menyangkut sumber download, unsur etika, aktualisasi konten, dan kapabilitas/kredibilitas konten, variasi jawaban responden terhadap hal ini cukup beragam dan kecenderungan di tiap provinsi berbeda-beda.

\section{KESIMPULAN}

Seperti sudah dikemukakan pada bagian awal, penelitian ini berupaya mengetahui tingkat literasi TIK (ICT literacy) tenaga pendidik di lingkungan PNS di wilayah Provinsi Jambi, Provinsi Kepulauan Bangka Belitung (Babel), Provinsi Bengkulu, dan Provinsi DKI Jakarta. Telaahannya sendiri mengacu pada rumusan masalah penelitian, yaitu: Seberapa jauh tingkat literasi informasi (information literacy) PNS tenaga pendidik?

Dengan mengacu pada temuan dan analisis penelitian, maka dapatlah diambil kesimpulan sebagai berikut:

Tingkat literasi informasi (information literacy) tenaga pendidik di lingkungan PNS, hal ini diukur dari lima aspek kemampuan. Lima aspek kemampuan itu mencakup kemampuan menggunakan peralatan (tools literacy), kemampuan sumber (resource literacy), kemampuan mempublikasi secara elektronik (publishing literacy), kemampuan beradaptasi dengan kemajuan teknologi (emerging technology literacy), dan kemampuan menyeleksi isi informasi secara kritis (critical literacy).

a. Kemampuan memahami dan menggunakan alat teknologi informasi secara praktik dan konseptual, termasuk software, hardware, dan multimedia (tools literacy), dapat dikatakan cukup memadai meskipun masih berada pada tingkat kemampuan standar.

b. Resource literacy, atau kemampuan memahami bentuk, format, lokasi, dan metode akses terhadap sumber-sumber informasi khususnya mengembangkan jaringan sumber-sumber informasi setiap hari, dapat dikatakan belum maksimal dalam arti masih terbatas pada pemanfaatan sedikit komponen sumber informasi serta metode pencarian/akses informasi

c. Publishing literacy, atau kemampuan memformat dan mem-publish riset dan idea secara elektronik, dalam bentuk secara tekstual dan multimedia (termasuk via World Wide Web, electronic mail, daftar distribusi, dan CD-ROMs), memperkenalkan mereka ke dalam publik elektronik secara nyata dan komunitas elektronik, masih belum maksimal.

d. Emerging technology literacy, atau kemampuan mudah beradaptasi, mengerti, menilai dan membuat secara kontinyu penemuan/inovasi dalam teknologi informasi, cukup baik.

e. Critical literacy, atau kemampuan melakukan penilaian secara kritis intelektual, human, kekuatan, dan kelemahan sosial, potensi-potensi dan batasan-batasan, keuntungan dan kerugian teknologi informasi

f. Dari hasil penelitian dapat dikatakan bahwa tingkat literasi informasi (information literacy) tenaga pendidik di lingkungan PNS di Provinsi Jambi sudah baik namun masih perlu mendapat perhatian pada kemampuan yang menyangkut publishing literacy, di Provinsi Babel dan Provinsi DKI Jakarta sudah baik, sedangkan di Provinsi Bengkulu masih kurang terutama pada kemampuan publishing literacy, resource literacy, dan critical literacy.

Berdasarkan hasil penelitian dapat diajukan beberapa saran yakni:

a. Literasi informasi sangat penting dimiliki oleh seorang tenaga pendidik yang memiliki tugas untuk mencerdaskan anak bangsa. Karena itu perlu dilakukannya berbagai pelatihan (diklat) secara reguler bagi kalangan pendidik sehingga dapat meningkatkan perannya secara maksimal dalam komunitas pendidikan dalam rangka meningkatkan ilmu, pemahaman, dan kreativitas.

b. Perlu diciptakannya tenaga pendidik yang dapat mengembangkan bahan ajar berbasis komputer/internet (Komputer/ Web Based), dan tenaga kependidikan yang dapat mengumpulkan, mengelola, 
memutahirkan, mengakuratkan, dan menyajikan materi pelajaran secara maksimal.

c. Melakukan perubahan (inovasi), serta peningkatan terhadap sarana prasarana pendidikan. Terutama dengan menggabungkan penggunaan teknologi (perangkat teknologi) dengan materi ajar sebagai media pembelajaran yang menarik, sehingga isi bahan ajar yang disajikan dapat tersampaikan secara maksimal untuk menunjang kelancaran dan peningkatan kualitas pendidikan.

\section{DAFTAR PUSTAKA}

Fitrihana, Noor. 2008. Kemampuan Literasi Informasi di Internet. Surakarta: Pusat Pengembangan Sistem Pembelajaran, Lembaga Pengembangan Pendidikan, Universitas Sebelas Maret.

Ministry of Communication and Information Technology: The Strategic Blue Print of Planning And Developing The ICTLiterate Human Resources in Indonesia" Version 1.0 - Desember 2006.
Readiness for the Networked World: A Guide for Developing Countries dan The Global Information Technology Report 2001-2002: Readiness for the Networked World.

Taufik, Tatang A. 2001. Survey Literasi Komputer: "Kesiapan Masyarakat di Era Informasi".

Telematika Indonesia, Kebijakan dan Perkembangan Tim Koordinasi Telematika Indonesia (TKPI), Kementerian Komunikasi dan Informasi RI, Jakarta, 2/004, 88

\section{Sumber Lain : \\ Internet :}

www.nuptk.info id.wikipedia.org

Educom Review, Volume 31, Number 2, March / April 1996. www.fctel.uncc.edu/pedagogy/resources/S evenDimensions.pdf

rettamd.blogspot.com

http://www.cilip.org.uk/professionalguidance/ informationliteracy/definition 